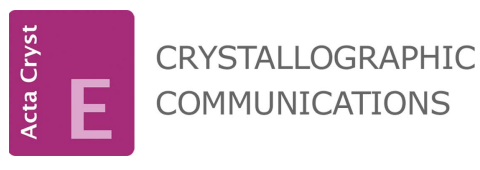

ISSN 2056-9890
Received 6 May 2020

Accepted 15 May 2020

Edited by M. Weil, Vienna University of Technology, Austria

Keywords: crystal structure; oxalamide; benzoic acid derivative; hydrogen bonding; Hirshfeld surface analysis; computational chemistry.

CCDC reference: 2004094

Supporting information: this article has supporting information at journals.iucr.org/e

\section{Crystal structure, Hirshfeld surface analysis and computational study of the 1:2 co-crystal formed between $N, N^{\prime}$-bis[(pyridin-4-yl)methyl]ethanedi- amide and 3-chlorobenzoic acid}

\author{
Sang Loon Tan and Edward R. T. Tiekink*
}

Research Centre for Crystalline Materials, School of Science and Technology, Sunway University, 47500 Bandar Sunway, Selangor Darul Ehsan, Malaysia. *Correspondence e-mail: edwardt@sunway.edu.my

The asymmetric unit of the title 1:2 co-crystal, $\mathrm{C}_{14} \mathrm{H}_{14} \mathrm{~N}_{4} \mathrm{O}_{2} \cdot 2 \mathrm{C}_{7} \mathrm{H}_{5} \mathrm{ClO}_{2}$, comprises a half-molecule of oxalamide $\left({ }^{4} \mathrm{LH}_{2}\right)$, being located about a centre of inversion, and a molecule of3-chlorobenzoic acid (3-ClBA) in a general position. From symmetry, the ${ }^{4} \mathrm{LH}_{2}$ molecule has a (+)antiperiplanar conformation with the 4-pyridyl residues lying to either side of the central, planar $\mathrm{C}_{2} \mathrm{~N}_{2} \mathrm{O}_{2}$ chromophore with the dihedral angle between the core and pyridyl ring being $74.69(11)^{\circ}$; intramolecular amide- $\mathrm{N}-\mathrm{H} \cdots \mathrm{O}$ (amide) hydrogen bonds are noted. The 3-ClBA molecule exhibits a small twist as seen in the $\mathrm{C}_{6} / \mathrm{CO}_{2}$ dihedral angle of $8.731(12)^{\circ}$. In the molecular packing, threemolecule aggregates are formed via carboxylic acid-O $-\mathrm{H} \cdots \mathrm{N}$ (pyridyl) hydrogen bonding. These are connected into a supramolecular tape along [111] through amide- $\mathrm{N}-\mathrm{H} \cdots \mathrm{O}$ (carbonyl) hydrogen bonding. Additional points of contact between molecules include pyridyl and benzoic acid-C$\mathrm{H} \cdots \mathrm{O}$ (amide), methylene- $\mathrm{C}-\mathrm{H} \cdots \mathrm{O}$ (carbonyl) and $\mathrm{C}-\mathrm{Cl} \cdots \pi$ (pyridyl) interactions so a three-dimensional architecture results. The contributions to the calculated Hirshfeld surface are dominated by $\mathrm{H} \cdots \mathrm{H}(28.5 \%), \mathrm{H} \cdots \mathrm{O} / \mathrm{O} \cdots \mathrm{H}$ $(23.2 \%), \mathrm{H} \cdots \mathrm{C} / \mathrm{C} \cdots \mathrm{H}(23.3 \%), \mathrm{H} \cdots \mathrm{Cl} / \mathrm{Cl} \cdots \mathrm{H}(10.0 \%)$ and $\mathrm{C} \cdot \mathrm{Cl} / \mathrm{C} \cdot \mathrm{Cl}$ $(6.2 \%)$ contacts. Computational chemistry confirms the $\mathrm{C}-\mathrm{Cl} \cdots \pi$ interaction is weak, and the importance of both electrostatic and dispersion terms in sustaining the molecular packing despite the strong electrostatic term provided by the carboxylic acid-O $-\mathrm{H} \cdots \mathrm{N}$ (pyridyl) hydrogen bonds.

\section{Chemical context}

Herein, the X-ray crystal structure determination of the 1:2 cocrystal formed between bis(pyridin-4-ylmethyl)ethanediamide and 3-chlorobenzoic acid, (I), is described. The present crystallographic study continues recent studies into the structural chemistry of the isomeric bis(pyridin- $n$-ylmethyl)ethanediamide molecules, i.e. species with the general formula $n$ $\mathrm{NC}_{5} \mathrm{H}_{4} \mathrm{CH}_{2} \mathrm{~N}(\mathrm{H}) \mathrm{C}(=\mathrm{O}) \mathrm{C}(=\mathrm{O}) \mathrm{CH}_{2} \mathrm{C}_{5} \mathrm{H}_{4} \mathrm{~N}-n$, for $n=2,3$ and 4 , and hereafter, abbreviated as ${ }^{n} \mathrm{LH}_{2}$ (Tiekink, 2017). These molecules have interest as co-crystal co-formers as they possess both hydrogen-bonding donating and accepting sites, i.e. amide and pyridyl functionalities. A particular focus of these studies has been upon co-crystals formed with carboxylic acids (Arman et al., 2012, 2014; Tan, Halcovitch et al., 2019; Tan \& Tiekink, 2019), directed by the reliability of the carboxylic acid-O-H. - N (pyridyl) synthon (Shattock et al., 2008). A common thread of recent investigations has been upon benzoic acid (Tan \& Tiekink, 2020a) and derivatives (Syed et al., 2016), in particular halide-substituted species (Tan \& 
Tiekink, 2020b) in order to probe for the possibility of competing/complementary halogen-bonding interactions. In connection with this theme, this report describes the crystal and molecular structures of (I), along with a detailed analysis of the supramolecular association through the calculation of the Hirshfeld surface and computational chemistry.<smiles>O=C(NCc1ccncc1)C(=O)NCc1ccncc1</smiles><smiles>O=C(O)c1cccc(Cl)c1</smiles>

\section{Structural commentary}

The asymmetric unit of (I) comprises a molecule of 4-chlorobenzoic acid (3-ClBA) in a general position and onehalf molecule of ${ }^{4} \mathrm{LH}_{2}$, being disposed about a centre of inversion, Fig. 1. In the acid, 3-ClBA, there is a definitive disparity in the $\mathrm{C} 8-\mathrm{O} 2 \quad[1.225(2) \AA]$ and $\mathrm{C} 8-\mathrm{O} 3$ [1.308 (2) A] bond lengths entirely consistent with the localization of the acidic proton on the $\mathrm{O} 3$ atom. This is also borne out in the angles subtended at the $\mathrm{C} 8$ atom with the widest angle involving the oxygen atoms $[\mathrm{O} 2-\mathrm{C} 8-\mathrm{O} 3=$ $123.38(17)^{\circ}$ ] and the narrowest involving the atoms connected by a single bond $\left[\mathrm{O} 3-\mathrm{C} 8-\mathrm{C} 9=114.23(15)^{\circ}\right]$. A small twist in the molecule is evident as seen in the dihedral angle of $8.731(12)^{\circ}$ formed between the $\mathrm{CO}_{2} / \mathrm{C}_{6}$ residues; the $\mathrm{O} 2-$ $\mathrm{C} 8-\mathrm{C} 9-\mathrm{C} 10$ torsion angle $=171.79$ (19) $\AA$.

The ${ }^{4} \mathrm{LH}_{2}$ molecule is situated about a centre of inversion so the central $\mathrm{C}_{2} \mathrm{~N}_{2} \mathrm{O}_{2}$ chromophore is constrained to be planar. As is normal for ${ }^{n} \mathrm{LH}_{2}$ molecules (Tiekink, 2017), the central C7-C7 $7^{\mathrm{i}}[1.539$ (3) $\AA$; symmetry code: (i) $1-x,-y,-z]$ bond

(a)

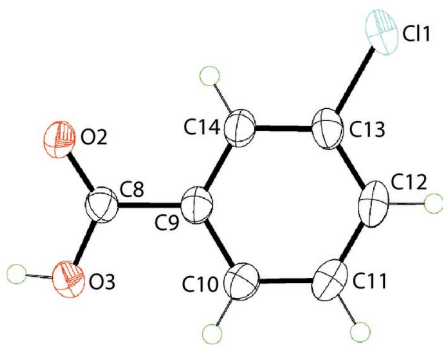

(b)

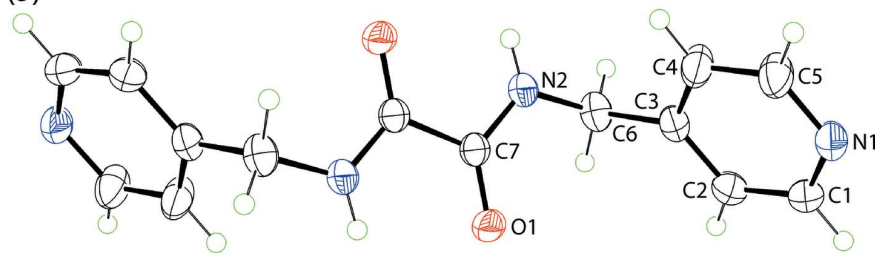

Figure 1

The molecular structures of the constituents of co-crystal (I) showing the atom-labelling scheme and displacement ellipsoids at the $50 \%$ probability level: $(a)$ the 3-chlorobenzoic acid molecule and $(b)$ the centrosymmetric $N, N^{\prime}$-bis[(pyridin-4-yl)methyl]oxalamide molecule with the unlabelled atoms related by the symmetry operation (i) $1-x,-y,-z$.
Table 1

Hydrogen-bond geometry $\left(\AA,^{\circ}\right)$.

$C g 1$ is the centroid of the $(\mathrm{N} 1, \mathrm{C} 1-\mathrm{C} 5)$ ring.

\begin{tabular}{lllll}
\hline$D-\mathrm{H} \cdots A$ & $D-\mathrm{H}$ & $\mathrm{H} \cdots A$ & $D \cdots A$ & $D-\mathrm{H} \cdots A$ \\
\hline $\mathrm{N} 2-\mathrm{H} 2 N \cdots \mathrm{O} 1^{\mathrm{i}}$ & $0.86(2)$ & $2.34(3)$ & $2.717(2)$ & $107(2)$ \\
$\mathrm{N} 2-\mathrm{H} 2 N \cdots \mathrm{O} 2^{\mathrm{ii}}$ & $0.86(2)$ & $2.08(2)$ & $2.863(2)$ & $151(2)$ \\
$\mathrm{O} 3-\mathrm{H} 3 O \cdots 1^{\mathrm{iii}}$ & $0.84(2)$ & $1.74(2)$ & $2.581(2)$ & $174(4)$ \\
$\mathrm{C} 14-\mathrm{H} 14 \cdots 1^{\text {iv }}$ & 0.95 & 2.37 & $3.286(2)$ & 161 \\
$\mathrm{C} 1-\mathrm{H} 1 \cdots \mathrm{O} 1^{\mathrm{v}}$ & 0.95 & 2.39 & $3.286(3)$ & 157 \\
$\mathrm{C} 12-\mathrm{H} 12 \cdots \mathrm{O} 1^{\mathrm{vi}}$ & 0.95 & 2.46 & $3.328(3)$ & 152 \\
$\mathrm{C} 6-\mathrm{H} 6 A \cdots \mathrm{O} 3$ & 0.99 & 2.50 & $3.400(3)$ & 151 \\
$\mathrm{C} 13-\mathrm{C} 11 \cdots C g 1$ & $1.75(1)$ & $3.83(1)$ & $5.358(2)$ & $145(1)$ \\
\hline
\end{tabular}

Symmetry codes: (i) $-x+1,-y,-z$; (ii) $-x+1,-y+1,-z+1$; (iii) $x-1, y, z$; (iv) $x, y+1, z+1 ;(\mathrm{v})-x+2,-y+1,-z ;(\mathrm{vi}) x+1, y+1, z+1$.

length is considered long, an observation ascribed to the electronegative substituents bound to the $s p^{2}-\mathrm{C} 7$ atom. The conformation of the ${ }^{4} \mathrm{LH}_{2}$ molecule is (+)antiperiplanar so the 4-pyridyl residues lie to either side of the planar region of the molecule. The dihedral angle between the central core and the N1-pyridyl ring is $74.69(11)^{\circ}$. Owing to the anti-disposition of the amide groups intramolecular amide- $\mathrm{N}-\mathrm{H} \cdots \mathrm{O}$ (amide) hydrogen bonds are formed which complete $S(5)$ loops, Table 1 .

\section{Supramolecular features}

The most distinctive feature of the molecular packing is the association between ${ }^{4} \mathrm{LH}_{2}$ and two symmetry-related 3-ClBA molecules via carboxylic acid-O $-\mathrm{H} \cdots \mathrm{N}$ (pyridyl) hydrogen bonding, Table 1, to generate a three-molecule aggregate. These three-molecule aggregates are connected into a linear tape along [111] via amide- $\mathrm{N}-\mathrm{H} \cdots \mathrm{O}$ (carbonyl) hydrogen bonds Fig. 2(a). These give rise to 22-membered $\left\{\cdots \mathrm{NC}_{4} \mathrm{NH} \cdots \mathrm{OCOH}\right\}_{2}$ synthons. Additional stability to the
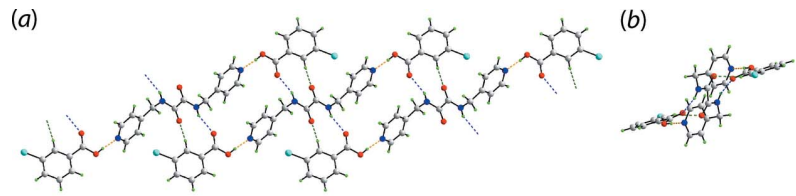

(c)
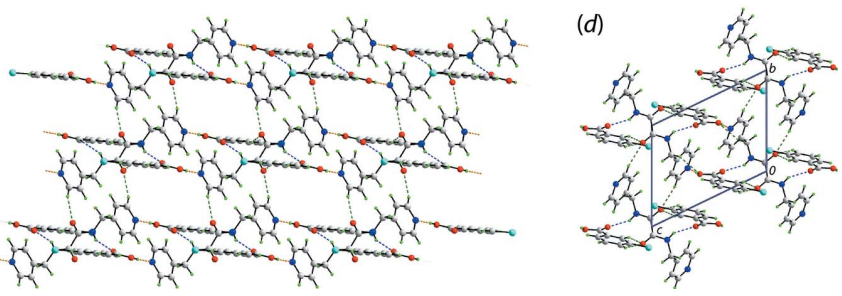

Figure 2

Molecular packing in the crystal of (I): (a) a view of the supramolecular tape comprising three-molecule aggregates (sustained by carboxylic acid$\mathrm{O}-\mathrm{H} \cdots \mathrm{N}$ (pyridyl) hydrogen bonding shown as orange dashed lines) linked by amide- $\mathrm{N}-\mathrm{H} \cdots \mathrm{O}$ (carbonyl) hydrogen bonding (blue dashed lines) and supporting benzoic acid- $\mathrm{C}-\mathrm{H} \cdots \mathrm{O}$ (carbonyl) interactions (green dashed lines), (b) an end-on view of the tape viewed down [111], (c) a view of the supramolecular layer whereby the tapes of $(a)$ are linked by short pyridyl-C $-\mathrm{H} \cdots \mathrm{O}$ (carbonyl) interactions and $(d)$ a view of the unit-cell contents down the $a$ axis. 
Table 2

A summary of short interatomic contacts $(\AA)$ for $(\mathrm{I})^{a}$.

\begin{tabular}{lll}
\hline Contact & Distance & Symmetry operation \\
\hline $\mathrm{H} 2 N \cdots \mathrm{O} 2^{b}$ & 1.95 & $1-x, 2-y, 1-z$ \\
$\mathrm{H} 3 O \cdots \mathrm{N} 1^{b}$ & 1.60 & $1-x, 2-y, 1-z$ \\
$\mathrm{H} 1 \cdots \mathrm{O} 1$ & 2.27 & $-1+x,-1+y, 1+z$ \\
$\mathrm{H} 6 A \cdots \mathrm{O} 3$ & 2.42 & $-1+x,-1+y, 1+z$ \\
$\mathrm{H} 12 \cdots \mathrm{O} 1$ & 2.34 & $1-x, 1-y, 1-z$ \\
$\mathrm{H} 14 \cdots \mathrm{O} 1$ & 2.25 & $x, y, z$ \\
$\mathrm{H} 4 \cdots \mathrm{C} 11$ & 2.66 & $1-x, 1-y, 1-z$ \\
$\mathrm{C} 10 \cdots \mathrm{C} 10$ & 3.28 & $2-x, 2-y, 1-z$ \\
\hline
\end{tabular}

Notes: (a) The interatomic distances are calculated in Crystal Explorer 17 (Turner et al., 2017) whereby the $X-\mathrm{H}$ bond lengths are adjusted to their neutron values; $(b)$ these interactions correspond to conventional hydrogen bonds.

hydrogen-bonding arrangement is provided by supporting benzoic acid-C14- $\mathrm{H} \cdots \mathrm{O}$ (amide) interaction which lead to non-symmetric 10 -membered $\left\{\cdots \mathrm{HC}_{3} \mathrm{O} \cdots \mathrm{HNC}_{2} \mathrm{O}\right\}_{2}$ synthons, which flank the larger 22-membered rings. Further, a complementary $\mathrm{C}-\mathrm{Cl} \cdots \pi$ (pyridyl) contact is noted, as detailed in Table 1. A survey of the literature (Imai et al., 2008) as well as the Cambridge Structural Database (Groom et al., 2016) shows that the average $\mathrm{Cl} \cdots \pi$ distance is about $3.6 \AA$, which is shorter than the contact distance in (I). An end-on view of the tape is shown in Fig. 2(b). The tapes are connected into a supramolecular layer by relatively short pyridyl-C1H...O(amide) contacts, Fig. 2(c). A three-dimensional architecture results when benzoic acid-C12-H...O(amide) and methylene-C$-\mathrm{H} \cdots \mathrm{O}$ (carbonyl) interactions are taken into consideration, Fig. $2(d)$. In this scheme, the amide-O1 atom participates in three pivotal $\mathrm{C}-\mathrm{H}$.. O interactions.

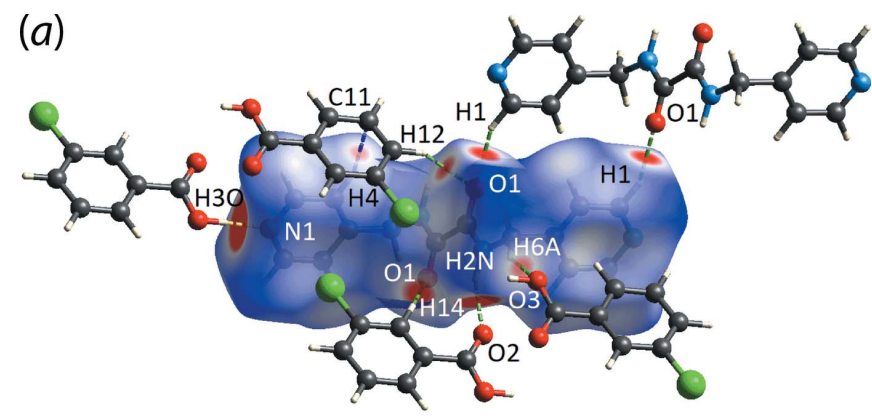

(b)

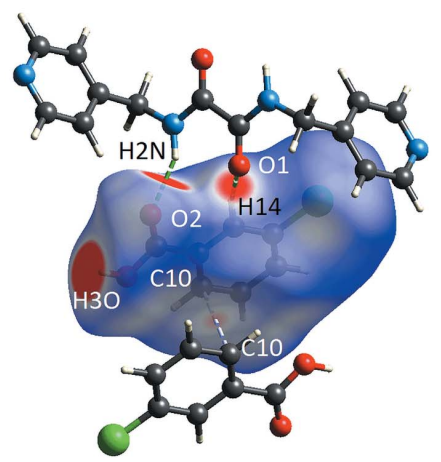

Figure 3

The $d_{\text {norm }}$ maps plotted within the range of -0.2015 to 1.0590 arbitrary units for $(a){ }^{4} \mathrm{LH}_{2}$ and (b) 3-ClBA, showing $\mathrm{O}-\mathrm{H} \cdots \mathrm{N}$ (yellow dashed lines), (N,C) $-\mathrm{H} \cdots \mathrm{O}$ (green dashed lines), $\mathrm{C}-\mathrm{H} \cdots \mathrm{C}$ (blue dashed lines) and $\mathrm{C} \cdots \mathrm{C}$ (light-purple dashed lines) close contacts as indicated by the corresponding red spots of varying intensity.

\section{Hirshfeld surface analysis}

The Hirshfeld surface analysis was performed for the threemolecule aggregate of (I), i.e. that sustained by the carboxylic acid-O $-\mathrm{H} \cdots \mathrm{N}$ (pyridyl) hydrogen bonds, and for the individual components, viz. the full molecule of ${ }^{4} \mathrm{LH}_{2}$ and 3-ClBA, with the use of CrystalExplorer17 (Turner et al., 2017) and based on established methods (Tan, Jotani et al., 2019). As shown in the images of Fig. 3, the analysis reveals there are several red spots of variable intensity observed on the $d_{\text {norm }}$ maps calculated for ${ }^{4} \mathrm{LH}_{2}$ and 3-ClBA. These are indicative of close contact distances shorter than the van der Waals radii (Spackman \& Jayatilaka, 2009). Specifically, red spots with intensity in decreasing order are observed for hydroxyl-O3$\mathrm{H} 3 O \cdots \mathrm{N} 1$ (pyridyl), amide- $\mathrm{N} 2-\mathrm{H} 2 N \cdots \mathrm{O} 2$ (carbonyl), pyrid-

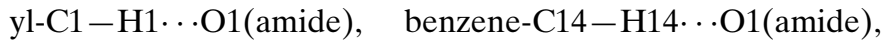
benzene-C12-H12 ‥O1(amide) and methylene-C6-H6A ...O3(hydroxyl); the $d_{\text {norm }}$ distances for these short contacts are given in Table 2. While the identified close contacts are consistent with those obtained from PLATON analysis (Spek, 2020), additional red spots are noted for pyridyl-C4$\mathrm{H} 4$..C11(benzene) as well as benzyl-C10 ..C10(benzene), albeit with relatively weaker intensity than the other inter-

(a)

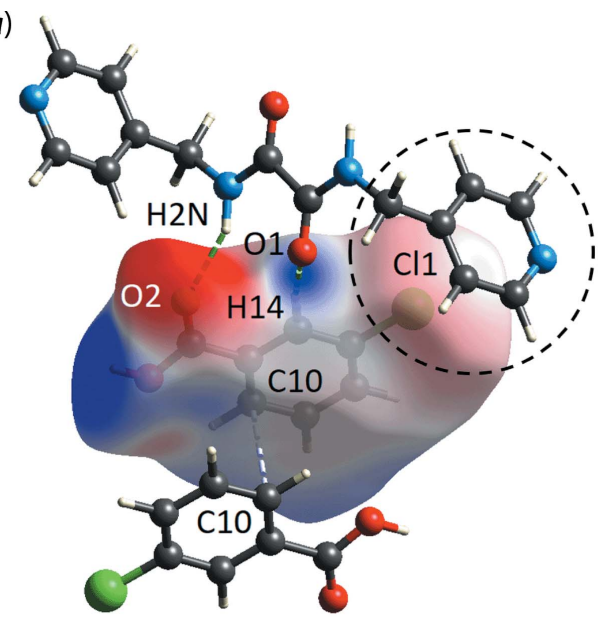

(b)

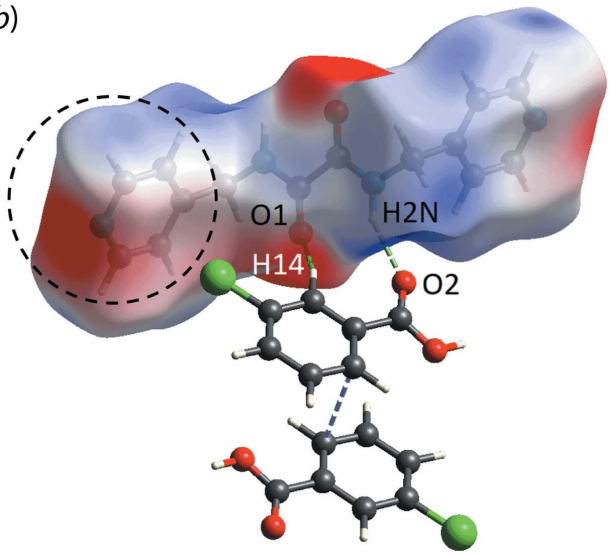

Figure 4

The electrostatic potential mapped onto the Hirshfeld surfaces within the isosurface value of -0.0481 to 0.0854 atomic units for $(a)$ 3-ClBA and $(b)$ ${ }^{4} \mathrm{LH}_{2}$. The circles highlight the interaction between the $\mathrm{Cl}$ atom, through the $\sigma$-hole region, and $\pi$-hole of the pyridyl ring. 
actions mentioned above. As for the $\mathrm{C} 13-\mathrm{Cl} 1 \cdots \pi(\mathrm{N} 1, \mathrm{C} 1-\mathrm{C} 5)$ contact, Table 2, the Hirshfeld surface analysis reveals only a faint-blue spot around the tip of Cl1 in Fig. 3(b) indicating the contact distance that is slightly less than the sum of the van der Waals radii (Spackman \& Jayatilaka, 2009).

To verify the nature of the $\mathrm{Cl} \cdots \pi$ contact in (I), the coformers were subjected to electrostatic potential mapping through DFT-B3LYP/6-31G $(d, p)$, as available in CrystalExplorer17. The analysis indicates that the $\mathrm{Cl} \cdots \pi$ interaction is weak in nature as evidenced from the white spot around the $\sigma$-hole region about the $\mathrm{Cl} 1$ atom in Fig. 4(a) as well as the faint-red spot around the centre of the $\pi$-ring centre, Fig. 4(b). A detailed study on the localized electrostatic charges shows that the $\sigma$-hole of $\mathrm{Cl} 1$ is about -0.0072 a.u. while the pyridyl $\pi$-hole is about -0.1270 a.u. indicating that the interaction is rather dispersive in nature. This observation is in contrast with other charge complementary interactions as shown from the intense blue (i.e. electropositive) and red (i.e. electronegative) regions on the electrostatic surface map. For instance, the amide-N2 $-\mathrm{H} 2 N \cdots \mathrm{O} 2$ (carbonyl) hydrogen bond has a pointto-point electrostatic charge of 0.1438 a.u. for $\mathrm{H} 2 \mathrm{~N}$ and -0.0622 a.u. for $\mathrm{O} 2$, suggestive of a strong interaction, while benzene-C14-H14 ‥O1(amide) shows complementary charges of 0.0427 and -0.0486 a.u. for $\mathrm{H} 14$ and O1, respectively, being indicative of a relatively weaker interaction. Among all the identified close contacts, hydroxyl-O3$\mathrm{H} 3 O \cdots \mathrm{N} 1$ (pyridyl) is considered to be the strongest exhibiting a marked difference in the electrostatic charge of 0.2919 a.u. for $\mathrm{H} 3 \mathrm{O}$ and -0.0727 a.u. for N1.
The three-molecule-aggregate of (I) as well as its individual co-formers, i.e. ${ }^{4} \mathrm{LH}_{2}$ and 3-ClBA, were subjected to fingerprint analysis for quantification of the close contacts for each entity, Fig. 5(a). Overall (I) exhibits a paw-like fingerprint profile which can be delineated into $\mathrm{H} \cdots \mathrm{H}(28.5 \%), \mathrm{H} \cdots \mathrm{O} /$ $\mathrm{O} \cdots \mathrm{H}(23.2 \%), \mathrm{H} \cdots \mathrm{C} / \mathrm{C} \cdots \mathrm{H}(23.3 \%), \mathrm{H} \cdots \mathrm{N} / \mathrm{N} \cdots \mathrm{H}(2.2 \%)$, $\mathrm{H} \cdots \mathrm{Cl} / \mathrm{Cl} \cdots \mathrm{H}(10.0 \%)$ and $\mathrm{C} \cdots \mathrm{Cl} / \mathrm{C} \cdots \mathrm{Cl}(6.2 \%)$, as illustrated in Fig. 5(b)-(f); others contacts amount to $6.6 \%$, constituting contacts less than $2.0 \%$ each. Among those contacts for (I), only $\mathrm{H} \cdots \mathrm{O} / \mathrm{O} \cdots \mathrm{H}$ and $\mathrm{H} \cdots \mathrm{C} / \mathrm{C} \cdots \mathrm{H}$ exhibit minimum $d_{\mathrm{i}}+d_{\mathrm{e}}$ contact distances tipped at $c a 1.94$ and $2.08 \AA$, respectively, significantly less than their respective sums of van der Waals radii of 2.61 and $2.79 \AA$; the remaining contacts occur at distances greater than their corresponding sums of van der Waals radii.

A similar paw-like fingerprint profile is observed for the overall fingerprint plots of the individual ${ }^{4} \mathrm{LH}_{2}$ and 3-ClBA molecules. The key difference between these and that for (I) is the asymmetry in the distributions owing to the interdependency of the intermolecular interactions between the two co-formers. For ${ }^{4} \mathrm{LH}_{2}$, the major contacts comprise $\mathrm{H} \cdots \mathrm{H}$ $(34.5 \%), \quad \mathrm{H} \cdots \mathrm{O} / \mathrm{O} \cdots \mathrm{H} \quad(22.1 \%), \quad \mathrm{H} \cdots \mathrm{C} / \mathrm{C} \cdots \mathrm{H} \quad(20.3 \%)$, $\mathrm{H} \cdots \mathrm{N} / \mathrm{N} \cdots \mathrm{H}(8.4 \%), \mathrm{H} \cdots \mathrm{Cl} / \mathrm{Cl} \cdots \mathrm{H}(6.4 \%)$ and $\mathrm{C} \cdots \mathrm{Cl}$ (5.0\%). A detailed analysis on the corresponding contacts reveals that the (internal)-H...O-(external) and (internal)$\mathrm{H}$...C-(external) contacts are slightly more dominant over the (internal)-O $\cdots \mathrm{H}$-(external) and (internal)-C..H-(external) counterparts with the distribution of the contacts being 12.7 and $11.2 \%$ versus 9.4 and $9.1 \%$, while the opposite is true for (a)
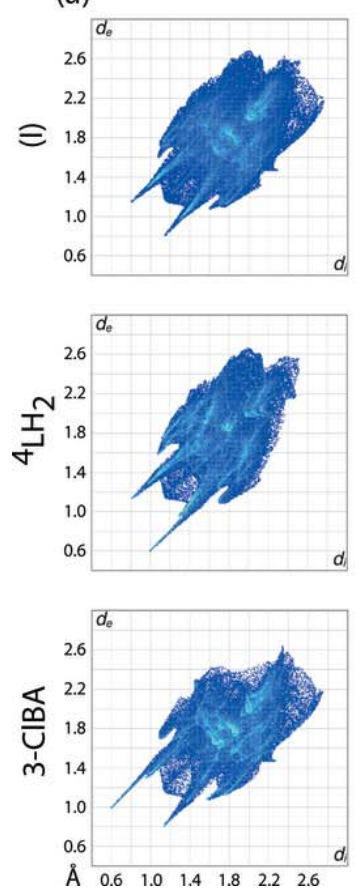

(b)
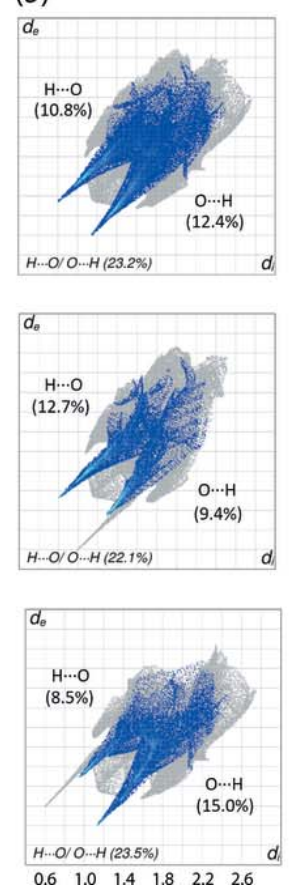

(c)
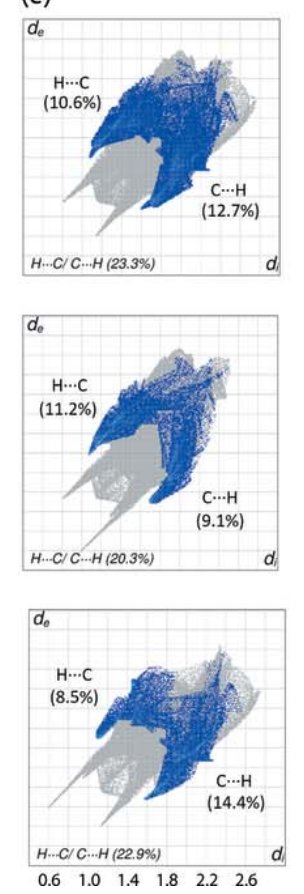

(d)
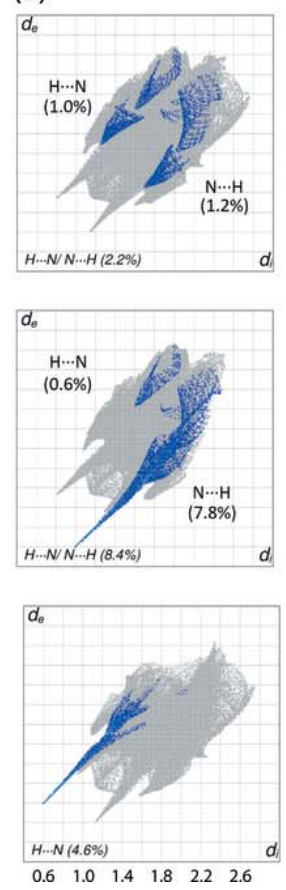

(e)
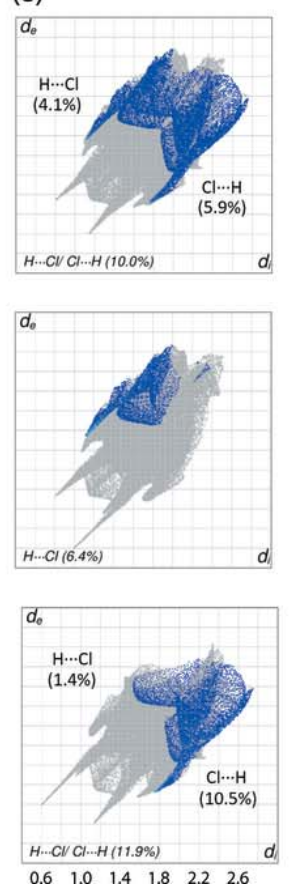

$(f)$
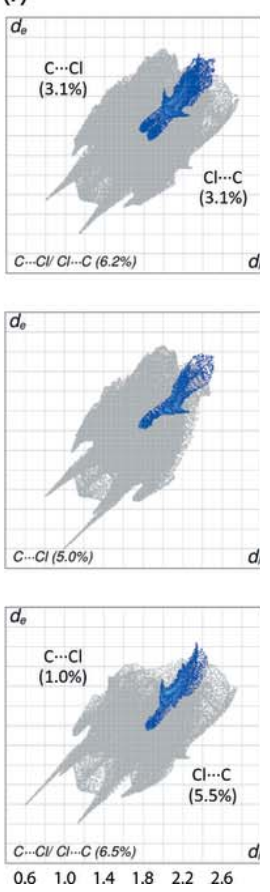

Figure 5

(a) The overall two-dimensional fingerprint plots for $(\mathrm{I}),{ }^{4} \mathrm{LH}_{2}$ and 3-ClBA, and those delineated into $(b) \mathrm{H} \cdots \mathrm{O} / \mathrm{O} \cdots \mathrm{H},(c) \mathrm{H} \cdots \mathrm{C} / \mathrm{C} \cdots \mathrm{H},(d) \mathrm{H} \cdots \mathrm{N} /$ $\mathrm{N} \cdots \mathrm{H},(e) \mathrm{H} \cdots \mathrm{Cl} / \mathrm{Cl} \cdots \mathrm{H}$ and $(f) \mathrm{C} \cdots \mathrm{Cl}$ contacts, with the percentage contributions specified within each plot. 
Table 3

A summary of interaction energies $\left(\mathrm{kJ} \mathrm{mol}^{-1}\right)$ calculated for (I).

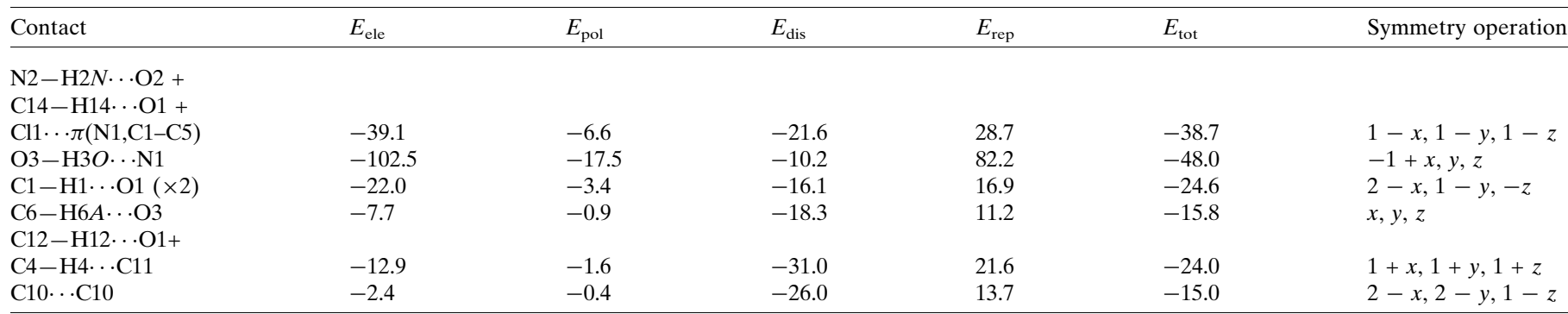

the (internal)-H. $\cdot \mathrm{N}$-(external) contact with a distribution of $0.6 \%$ as compared to $7.8 \%$ for (internal)- $\mathrm{N} \cdot \mathrm{H}$-(external). The stark difference in the dominance for $\mathrm{H} \cdots \mathrm{N} / \mathrm{N} \cdots \mathrm{H}$ is likely due to the amide- $\mathrm{H}$ forming a hydrogen bond to $\mathrm{O}$ (carbonyl) rather than to a nitrogen acceptor. Among the major contacts, (internal)-H...O-(external) and (internal)$\mathrm{N} \cdot \mathrm{H}$-(external) display minimum $d_{\mathrm{i}}+d_{\mathrm{e}}$ distances of about 1.94 and $1.60 \AA$, respectively, which are significantly shorter than the sums of the respective van der Waals radii as compared to the (internal)-O..H-(external) and (internal)$\mathrm{H} \cdot \mathrm{N}$-(external) counterparts of 2.24 and $3.62 \AA$, respectively. A similar observation is noted for (internal)-H...C(external) $(\sim 2.66 \AA)$ despite the deviation from the sum of the van der Waals radii (2.79 ̊) being less significant.

As for the individual 3-ClBA molecule, the major contacts in the overall fingerprint plot can be delineated into $\mathrm{H} \cdots \mathrm{O}$ / $\mathrm{O} \cdots \mathrm{H} \quad(23.5 \%), \mathrm{H} \cdots \mathrm{C} / \mathrm{C} \cdots \mathrm{H} \quad(22.9 \%), \mathrm{H} \cdots \mathrm{H} \quad(21.8 \%)$, $\mathrm{H} \cdots \mathrm{Cl} / \mathrm{Cl} \cdots \mathrm{H}(11.9 \%), \mathrm{C} \cdots \mathrm{Cl} / \mathrm{Cl} \cdots \mathrm{C}(6.5 \%)$ and $\mathrm{H} \cdots \mathrm{N} /$ $\mathrm{N} \cdot \cdot \mathrm{H}(4.6 \%)$. The trend of dominance is more inclined towards (internal)- $X \cdots Y$-(external) for some close contacts $(X=\mathrm{O}, \mathrm{C}$ and $\mathrm{Cl} ; Y=\mathrm{H}$ and $\mathrm{C}$ ), with the distribution being $15.0,14.4,10.5$ and $5.5 \%$ for $\mathrm{O} \cdots \mathrm{H}, \mathrm{C} \cdots \mathrm{H}, \mathrm{Cl} \cdots \mathrm{H}$ and Cl $\cdots \mathrm{C}$, respectively, compared to $8.5,8.5,1.4$ and $1.0 \%$ for the corresponding $\mathrm{H} \cdots \mathrm{O}, \mathrm{H} \cdots \mathrm{C}, \mathrm{H} \cdots \mathrm{Cl}$ and $\mathrm{C} \cdots \mathrm{Cl}$ counterparts. In term of $d_{\mathrm{i}}+d_{\mathrm{e}}$ contact distances, the key values are reciprocal to those for ${ }^{4} \mathrm{LH}_{2}$ owing to the interdependency of interactions as mentioned previously.

\section{Computational chemistry}

The calculation of the interaction energy for all pairwise molecules in (I) was performed through CrystalExplorer17 (Turner et al., 2017) following reported procedures (Tan, Jotani et al., 2019) with the purpose of studying the strength of each interaction identified from the Hirshfeld surface analysis. The results tabulated in Table 3 show that the carboxylic acid$\mathrm{O} 3-\mathrm{H} 3 O \cdots \mathrm{N} 1$ (pyridyl) hydrogen bond has the greatest interaction energy $\left(E_{\text {int }}\right)$ with the value being $-48.0 \mathrm{~kJ} \mathrm{~mol}^{-1}$, and this is followed by the dimeric amide-N2$\mathrm{H} 2 \mathrm{~N}$...O2(carbonyl), benzene-C14-H14...O1(amide) and Cl1 $\cdots \pi(\mathrm{N} 1, \mathrm{C} 1-\mathrm{C} 5)$ interactions, with a combined $E_{\text {int }}$ of $-38.7 \mathrm{~kJ} \mathrm{~mol}^{-1}$, the 16 -membered $\left\{\cdots \mathrm{OCNC}_{3} \mathrm{CH} \cdots\right\}$ heterosynthon involving pyridyl-C1 $-\mathrm{H} 1 \cdots \mathrm{O} 1$ (amide) interactions $\left(-24.6 \mathrm{~kJ} \mathrm{~mol}^{-1}\right)$, benzene-C12-H12 . O1(amide) and pyridyl-C4-H4.C.C11(benzene) with a combined $E_{\text {int }}$ of $-24.0 \mathrm{~kJ} \mathrm{~mol}^{-1}, \quad$ methylene-C6-H6A . O 3 (hydroxyl) $\left(-15.8 \mathrm{~kJ} \mathrm{~mol}^{-1}\right)$ as well as the benzene-C10 $\cdots \mathrm{C} 10$ (benzene) interaction with $\left(-15.0 \mathrm{~kJ} \mathrm{~mol}^{-1}\right)$. Interestingly, the strongest hydroxyl-O3 $-\mathrm{H} 3 \mathrm{O} \cdots \mathrm{N} 1$ (pyridyl) interaction in this crystal has an $E_{\text {int }}$ value that is only slightly less than that of -49.4 and $-52.0 \mathrm{~kJ} \mathrm{~mol}^{-1}$ ) (two independent molecules) displayed by an equivalent $\mathrm{O}-\mathrm{H} \cdot \mathrm{N}$ hydrogen bond complemented by a supporting pyridyl-C $-\mathrm{H}$... $\mathrm{O}$ (carbonyl) interaction in the isomeric 2:1 co-crystal of ${ }^{4} \mathrm{LH}_{2}$ with 4-ClBA (Tan \& Tiekink, $2020 b$ ); the supporting $\mathrm{C}-\mathrm{H} \cdots \mathrm{O}$ (carbonyl) contact is absent in $(\mathrm{I})$.
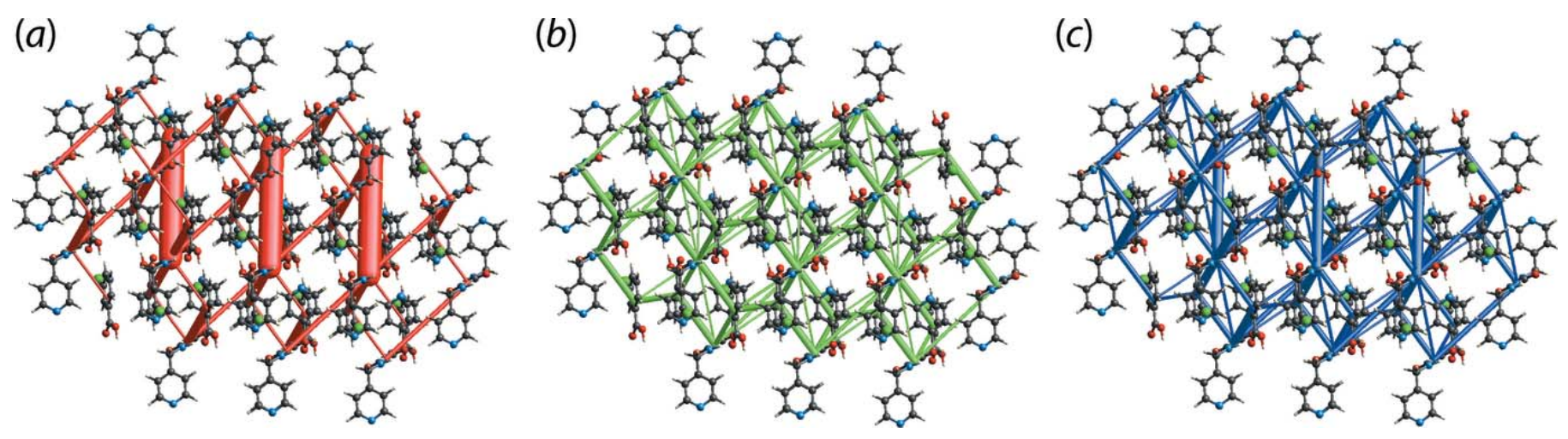

Figure 6

Perspective views of the energy frameworks of (I), showing the $(a)$ electrostatic force, $(b)$ dispersion force and $(c)$ total energy. The radius of the cylinders is proportional to the relative strength of the corresponding energies, and they were adjusted to the same scale factor of 100 with a cut-off value of $8 \mathrm{~kJ} \mathrm{~mol}^{-1}$ within $2 \times 2 \times 2$ unit cells. 
The co-crystal system is governed by a combination of electrostatic and dispersion forces leading to a three-dimensional wire mesh-like energy framework as shown in Fig. 6. In the electrostatic energy framework, the hydroxyl-O3$\mathrm{H} 3 O \cdots \mathrm{N} 1$ (pyridyl) interaction is the main foundation of the framework as evidenced from the thick cylindrical rods with other, relatively, thinner rods which ramify owing to various other $\mathrm{O} \cdots \mathrm{H}$ interactions, Fig. $6(a)$. The $\mathrm{O} \cdots \mathrm{H}$ interactions together with other complementary interactions are found to contribute to the dispersion energy framework which forms a similar topology as the electrostatic energy framework, Fig. 6(b). The combination of the other electrostatic and dispersion forces supersedes the strong interaction energy from the hydroxyl-O3-H3O $\cdots \mathrm{N} 1$ (pyridyl) hydrogen bonding and leads to the overall energy framework illustrated in Fig. 6(c) without dominant interactions in a given direction. It is interesting to note that despite being an isomeric analogue to the ${ }^{4} \mathrm{LH}_{2} \cdot 2$ (4-ClBA) co-crystal (Tan \& Tiekink, $2020 b$ ), (I) exhibits completely different topological frameworks as compared to the ladder-like frameworks of $4 \mathrm{LH}_{2} \cdot 2(4-\mathrm{ClBA})$.

\section{Database survey}

The aforementioned analogue of (I), ${ }^{4} \mathrm{LH}_{2} \cdot 2(4-\mathrm{ClBA})$ (Tan \& Tiekink, 2020b), is the most closely related, and indeed, isomeric co-crystal available for comparison; this too has been subjected to a detailed analysis of the molecular packing. Cocrystals (I) and (II) are not isostructural, with the asymmetric unit of (II) comprising two half-molecules of ${ }^{4} \mathrm{LH}_{2}$, i.e. ${ }^{4} \mathrm{LH}_{2}$ II $a$ and ${ }^{4} \mathrm{LH}_{2}-\mathrm{II} b$, as each is disposed about a centre of inversion, and two symmetry-independent molecules of 4ClBA, i.e. 4-ClBA-II $a$ and 4-ClBA-II $b$. The common feature of the molecular packing of (I) and (II) is the formation of two three-molecule aggregates. The key difference in the molecular packing relates to the nature of the supramolecular tapes: in (II), the tapes are sustained by a sequence of tenmembered $\{\cdots \mathrm{HNCCO}\}_{2}$ synthons, as highlighted in Fig. 7.

A comparison of the percentage contributions by the most prominent contacts to the respective Hirshfeld surfaces of (I) and (II), and including their individual components has been made (Jotani et al., 2019). The results are summarized in Fig. 8

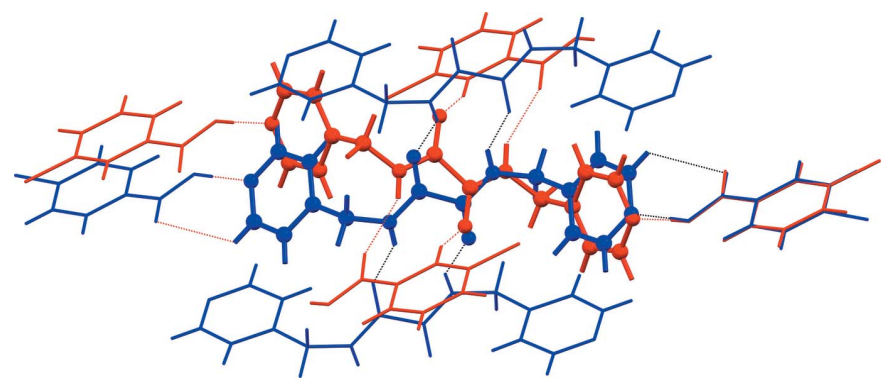

Figure 7

A comparison of the molecular packing in (I) (red) and (II) (blue), showing the differences in the molecular connectivities surrounding the central ${ }^{4} \mathrm{LH}_{2}$ molecule.

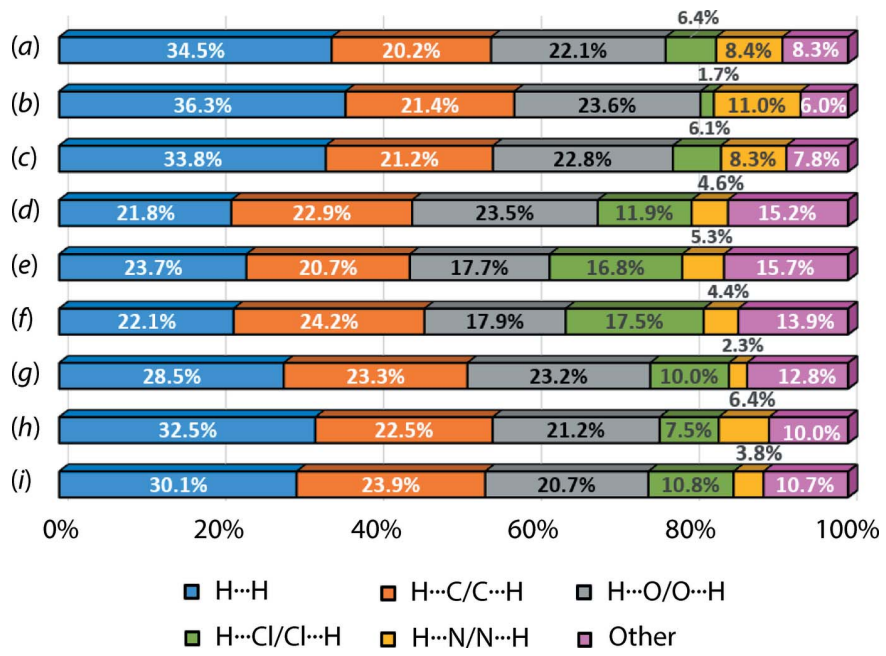

Figure 8

A comparison of the percentage contributions of the various contacts to the calculated Hirshfeld surfaces for $(a){ }^{4} \mathrm{LH}_{2} \mathrm{I},(b){ }^{4} \mathrm{LH}_{2}-\mathrm{II} a,(c){ }^{4} \mathrm{LH}_{2^{-}}$ $\mathrm{II} b,(d)$ 3-ClBA-I, (e) 4-ClBA-II $a,(f)$ 4-ClBA-III $b,(g)(\mathrm{I}),(h)(\mathrm{II} a)$ and $(i)$ (II $b)$.

and suggest that to a first approximation there are no dramatic variations between the contacts made to the Hirshfeld surfaces calculated for (I) and (II). Among the noticeable differences are due to the $\mathrm{H} \cdots \mathrm{O} / \mathrm{O} \cdots \mathrm{H}$ contacts which are greater for 3-ClBA, by 5.8 and $5.6 \%$, respectively than for 4ClBA-II $a$ and II $b$. This is compensated by a reduction in the $\mathrm{H} \cdots \mathrm{Cl} / \mathrm{Cl} \cdots \mathrm{H}$ contacts by 4.9 and $5.6 \%$. One possible reason for the increase in $\mathrm{O} \cdots \mathrm{H} / \mathrm{H} \cdots \mathrm{O}$ contacts in (I) $c f$. (II) relates to the participation of the carbonyl-O atom in formal hydrogen bonding to the amide- $\mathrm{N}-\mathrm{H}$ group and the prominent role of the amide-O1 atom in providing points of contact between molecules.

\section{Synthesis and crystallization}

The precursor, $\quad N, N^{\prime}$-bis[(pyridin-4-yl)methyl]oxalamide $\left({ }^{4} \mathrm{LH}_{2}\right)$ was prepared according to a literature procedure: M.p. 486.3-487.6 K; lit. 486-487 K (Nguyen et al., 1998). 3-Chlorobenzoic acid (Merck; 3-ClBA) was of reagent grade and used as received without further purification. The co-former ${ }^{4} \mathrm{LH}_{2}$ $(0.271 \mathrm{~g}, 0.001 \mathrm{~mol})$ was mixed with 3 -ClBA $(0.157 \mathrm{~g}$, $0.001 \mathrm{~mol}$ ) and the mixture was then ground for $15 \mathrm{~min}$ in the presence of a few drops of methanol. The procedure was repeated twice. Colourless blocks were obtained through careful layering of toluene $(1 \mathrm{ml})$ on an $N, N$-dimethylformamide solution $(1 \mathrm{ml})$ of the ground mixture. M.p. 436.6437.7 K. IR $\left(\mathrm{cm}^{-1}\right): 3280 v(\mathrm{~N}-\mathrm{H}), 3070-2919 v(\mathrm{C}-\mathrm{H}), 1703-$ $1656 v(\mathrm{C}=\mathrm{O}), 1524 v(\mathrm{C}=\mathrm{C}), 1415 v(\mathrm{C}-\mathrm{N}), 753 v(\mathrm{C}-\mathrm{Cl})$.

\section{Refinement}

Crystal data, data collection and structure refinement details are summarized in Table 4. The carbon-bound $\mathrm{H}$ atoms were placed in calculated positions $(\mathrm{C}-\mathrm{H}=0.95-0.99 \AA)$ and were included in the refinement in the riding-model approximation, 
with $U_{\text {iso }}(\mathrm{H})$ set to $1.2 U_{\text {eq }}(\mathrm{C})$. The oxygen- and nitrogenbound $\mathrm{H}$ atoms were located from a difference-Fourier map and refined with $\mathrm{O}-\mathrm{H}=0.84 \pm 0.01 \AA$ and $\mathrm{N}-\mathrm{H}=$ $0.86 \pm 0.01 \AA$, respectively, and with $U_{\text {iso }}(\mathrm{H})$ set to $1.5 U_{\text {eq }}(\mathrm{O})$ or $1.2 U_{\text {eq }}(\mathrm{N})$.

\section{Funding information}

Crystallographic research at Sunway University is supported by Sunway University Sdn Bhd (grant No. STR-RCTRRCCM-001-2019).

\section{References}

Arman, H. D., Kaulgud, T., Miller, T. \& Tiekink, E. R. T. (2014). Z. Kristallogr. Cryst. Mater. 229, 295-302.

Arman, H. D., Miller, T. \& Tiekink, E. R. T. (2012). Z. Kristallogr. Cryst. Mater. 227, 825-830.

Brandenburg, K. (2006). DIAMOND. Crystal Impact GbR, Bonn, Germany.

Farrugia, L. J. (2012). J. Appl. Cryst. 45, 849-854.

Groom, C. R., Bruno, I. J., Lightfoot, M. P. \& Ward, S. C. (2016). Acta Cryst. B72, 171-179.

Imai, Y. N., Inoue, Y., Nakanishi, I. \& Kitaura, K. (2008). Protein Sci. 17, 1129-1137.

Jotani, M. M., Wardell, J. L. \& Tiekink, E. R. T. (2019). Z. Kristallogr. Cryst. Mater. 234, 43-57.

Luong Nguyen, T., Scott, A., Dinkelmeyer, B., Fowler, F. W. \& Lauher, J. W. (1998). New J. Chem. 22, 129-135.

Rigaku OD (2018). CrysAlis PRO. Rigaku Corporation, Oxford, England.

Shattock, T. R., Arora, K. K., Vishweshwar, P. \& Zaworotko, M. J. (2008). Cryst. Growth Des. 8, 4533-4545.

Sheldrick, G. M. (2015a). Acta Cryst. A71, 3-8.

Sheldrick, G. M. (2015b). Acta Cryst. C71, 3-8.

Spackman, M. A. \& Jayatilaka, D. (2009). CrystEngComm, 11, 19-32.

Spek, A. L. (2020). Acta Cryst. E76, 1-11.

Syed, S., Jotani, M. M., Halim, S. N. A. \& Tiekink, E. R. T. (2016). Acta Cryst. E72, 391-398.

Tan, S. L., Halcovitch, N. R. \& Tiekink, E. R. T. (2019). Acta Cryst. E75, 1133-1139.

Tan, S. L., Jotani, M. M. \& Tiekink, E. R. T. (2019). Acta Cryst. E75, 308-318.

Tan, S. L. \& Tiekink, E. R. T. (2019). Z. Kristallogr. New Cryst. Struct. 234, 1109-1111.
Table 4

Experimental details.

\begin{tabular}{|c|c|}
\hline \multicolumn{2}{|l|}{ Crystal data } \\
\hline Chemical formula & $\mathrm{C}_{7} \mathrm{H}_{5} \mathrm{ClO}_{2} \cdot \mathrm{C}_{7} \mathrm{H}_{7} \mathrm{~N}_{2} \mathrm{O}$ \\
\hline$M_{\mathrm{r}}$ & 291.71 \\
\hline Crystal system, space group & Triclinic, $P \overline{1}$ \\
\hline Temperature $(\mathrm{K})$ & 100 \\
\hline$a, b, c(\AA)$ & 7.7817 (2), $9.5743(3), 11.1516(4)$ \\
\hline$\alpha, \beta, \gamma\left(^{\circ}\right)$ & $113.721(3), 90.064(2), 112.397(3)$ \\
\hline$V\left(\AA^{3}\right)$ & $691.47(4)$ \\
\hline$Z$ & 2 \\
\hline Radiation type & $\mathrm{Cu} K \alpha$ \\
\hline$\mu\left(\mathrm{mm}^{-1}\right)$ & 2.54 \\
\hline Crystal size $(\mathrm{mm})$ & $0.17 \times 0.07 \times 0.06$ \\
\hline \multicolumn{2}{|l|}{ Data collection } \\
\hline Diffractometer & $\begin{array}{l}\text { XtaLAB Synergy, Dualflex, } \\
\text { AtlasS2 }\end{array}$ \\
\hline Absorption correction & $\begin{array}{l}\text { Gaussian (CrysAlis PRO; Rigaku } \\
\quad \text { OD, 2018) }\end{array}$ \\
\hline$T_{\min }, T_{\max }$ & $0.604,1.000$ \\
\hline $\begin{array}{l}\text { No. of measured, independent and } \\
\text { observed }[I>2 \sigma(I)] \text { reflections }\end{array}$ & $17474,2873,2589$ \\
\hline$R_{\text {int }}$ & 0.043 \\
\hline$(\sin \theta / \lambda)_{\max }\left(\AA^{-1}\right)$ & 0.631 \\
\hline \multicolumn{2}{|l|}{ Refinement } \\
\hline$R\left[F^{2}>2 \sigma\left(F^{2}\right)\right], w R\left(F^{2}\right), S$ & $0.047,0.128,1.07$ \\
\hline No. of reflections & 2873 \\
\hline No. of parameters & 189 \\
\hline No. of restraints & 2 \\
\hline $\mathrm{H}$-atom treatment & $\begin{array}{l}\mathrm{H} \text { atoms treated by a mixture of } \\
\text { independent and constrained } \\
\text { refinement }\end{array}$ \\
\hline$\Delta \rho_{\max }, \Delta \rho_{\min }\left(\mathrm{e} \AA^{-3}\right)$ & $0.61,-0.47$ \\
\hline
\end{tabular}

Computer programs: CrysAlis PRO (Rigaku OD, 2018), SHELXS (Sheldrick, 2015a), SHELXL2017/1 (Sheldrick, 2015b), ORTEP-3 for Windows (Farrugia, 2012), DIAMOND (Brandenburg, 2006) and publCIF (Westrip, 2010).

Tan, S. L. \& Tiekink, E. R. T. (2020a). Acta Cryst. E76, 102-110. Tan, S. L. \& Tiekink, E. R. T. (2020b). Acta Cryst. E76, 245-253.

Tiekink, E. R. T. (2017). Multi-Component Crystals: Synthesis, Concepts, Function, edited by E. R. T. Tiekink \& J. SchpectorZukerman, pp. 289-319. Singapore: De Gruyter.

Turner, M. J., Mckinnon, J. J., Wolff, S. K., Grimwood, D. J., Spackman, P. R., Jayatilaka, D. \& Spackman, M. A. (2017). Crystal Explorer 17. The University of Western Australia.

Westrip, S. P. (2010). J. Appl. Cryst. 43, 920-925. 


\section{supporting information}

Acta Cryst. (2020). E76, 870-876 [https://doi.org/10.1107/S2056989020006568]

Crystal structure, Hirshfeld surface analysis and computational study of the 1:2 co-crystal formed between $N, N^{\prime}$-bis[(pyridin-4-yl)methyl] ethanediamide and 3chlorobenzoic acid

\section{Sang Loon Tan and Edward R. T. Tiekink}

Computing details

Data collection: CrysAlis PRO (Rigaku OD, 2018); cell refinement: CrysAlis PRO (Rigaku OD, 2018); data reduction: CrysAlis PRO (Rigaku OD, 2018); program(s) used to solve structure: SHELXS (Sheldrick, 2015a); program(s) used to refine structure: SHELXL2017/1 (Sheldrick, 2015b); molecular graphics: ORTEP-3 for Windows (Farrugia, 2012), DIAMOND (Brandenburg, 2006); software used to prepare material for publication: publCIF (Westrip, 2010).

N,N'-Bis[(pyridin-4-yl)methyl]ethanediamide-3-chlorobenzoic acid (1/1)

Crystal data

$\mathrm{C}_{7} \mathrm{H}_{5} \mathrm{ClO}_{2} \cdot \mathrm{C}_{7} \mathrm{H}_{7} \mathrm{~N}_{2} \mathrm{O}$

$M_{r}=291.71$

Triclinic, $P \overline{1}$

$a=7.7817(2) \AA$

$b=9.5743(3) \AA$

$c=11.1516(4) \AA$

$\alpha=113.721(3)^{\circ}$

$\beta=90.064(2)^{\circ}$

$\gamma=112.397(3)^{\circ}$

$V=691.47(4) \AA^{3}$

\section{Data collection}

XtaLAB Synergy, Dualflex, AtlasS2 diffractometer

Radiation source: micro-focus sealed X-ray tube, PhotonJet $(\mathrm{Cu}) \mathrm{X}$-ray Source

Mirror monochromator

Detector resolution: 5.2558 pixels $\mathrm{mm}^{-1}$

$\omega$ scans

Absorption correction: gaussian

(CrysAlisPro; Rigaku OD, 2018)

Refinement

Refinement on $F^{2}$

Least-squares matrix: full

$R\left[F^{2}>2 \sigma\left(F^{2}\right)\right]=0.047$

$w R\left(F^{2}\right)=0.128$

$S=1.07$

2873 reflections
$Z=2$

$F(000)=302$

$D_{\mathrm{x}}=1.401 \mathrm{Mg} \mathrm{m}^{-3}$

$\mathrm{Cu} K \alpha$ radiation, $\lambda=1.54184 \AA$

Cell parameters from 7027 reflections

$\theta=5.4-76.0^{\circ}$

$\mu=2.54 \mathrm{~mm}^{-1}$

$T=100 \mathrm{~K}$

Rhombohedral, colourless

$0.17 \times 0.07 \times 0.06 \mathrm{~mm}$

$T_{\min }=0.604, T_{\max }=1.000$

17474 measured reflections

2873 independent reflections

2589 reflections with $I>2 \sigma(I)$

$R_{\text {int }}=0.043$

$\theta_{\max }=76.6^{\circ}, \theta_{\min }=4.4^{\circ}$

$h=-9 \rightarrow 9$

$k=-12 \rightarrow 12$

$l=-13 \rightarrow 13$

189 parameters

2 restraints

Primary atom site location: dual

Hydrogen site location: mixed

$\mathrm{H}$ atoms treated by a mixture of independent and constrained refinement 
$w=1 /\left[\sigma^{2}\left(F_{\mathrm{o}}^{2}\right)+(0.0629 P)^{2}+0.363 P\right]$

where $P=\left(F_{\mathrm{o}}^{2}+2 F_{\mathrm{c}}^{2}\right) / 3$

$(\Delta / \sigma)_{\max }<0.001$

$$
\begin{aligned}
\Delta \rho_{\max } & =0.61 \text { e } \AA^{-3} \\
\Delta \rho_{\text {m. }} & =-0.47 \AA^{-3}
\end{aligned}
$$

$\Delta \rho_{\min }=-0.47$ e $\AA^{-3}$

Special details

Geometry. All esds (except the esd in the dihedral angle between two 1.s. planes) are estimated using the full covariance matrix. The cell esds are taken into account individually in the estimation of esds in distances, angles and torsion angles; correlations between esds in cell parameters are only used when they are defined by crystal symmetry. An approximate (isotropic) treatment of cell esds is used for estimating esds involving 1.s. planes.

Fractional atomic coordinates and isotropic or equivalent isotropic displacement parameters $\left(\AA^{2}\right)$

\begin{tabular}{|c|c|c|c|c|}
\hline & $x$ & $y$ & $z$ & $U_{\text {iss }} * / U_{\text {eq }}$ \\
\hline $\mathrm{Cl} 1$ & $1.16272(7)$ & $1.19147(7)$ & $0.97323(5)$ & $0.04950(19)$ \\
\hline $\mathrm{O} 2$ & $0.52027(18)$ & $0.7929(2)$ & 0.61549 (14) & $0.0462(4)$ \\
\hline $\mathrm{O} 3$ & $0.61166(18)$ & $0.70870(18)$ & $0.41896(13)$ & $0.0379(3)$ \\
\hline $\mathrm{H} 3 \mathrm{O}$ & $0.4966(19)$ & $0.676(4)$ & $0.389(3)$ & $0.080(10)^{*}$ \\
\hline $\mathrm{C} 8$ & $0.6450(2)$ & $0.7875(2)$ & $0.54909(18)$ & $0.0323(4)$ \\
\hline $\mathrm{C} 9$ & $0.8502(2)$ & $0.8715(2)$ & $0.61122(18)$ & $0.0314(4)$ \\
\hline $\mathrm{C} 10$ & $0.9858(3)$ & $0.8450(2)$ & $0.5341(2)$ & $0.0337(4)$ \\
\hline H10 & 0.949112 & 0.774182 & 0.441116 & $0.040^{*}$ \\
\hline C11 & $1.1744(3)$ & $0.9230(3)$ & $0.5943(2)$ & $0.0383(4)$ \\
\hline H11 & 1.266423 & 0.903127 & 0.542180 & $0.046^{*}$ \\
\hline $\mathrm{C} 12$ & $1.2306(3)$ & $1.0291(3)$ & $0.7289(2)$ & $0.0385(4)$ \\
\hline H12 & 1.360150 & 1.082595 & 0.769580 & $0.046^{*}$ \\
\hline $\mathrm{C} 13$ & $1.0942(3)$ & $1.0560(2)$ & $0.8034(2)$ & $0.0358(4)$ \\
\hline C14 & $0.9041(2)$ & $0.9776(2)$ & 0.74687 (19) & $0.0341(4)$ \\
\hline H14 & 0.812284 & 0.996077 & 0.799770 & $0.041^{*}$ \\
\hline $\mathrm{O} 1$ & $0.62312(17)$ & $0.12645(16)$ & $-0.07710(13)$ & $0.0330(3)$ \\
\hline N1 & $1.2621(2)$ & $0.5924(2)$ & $0.31316(17)$ & $0.0383(4)$ \\
\hline $\mathrm{N} 2$ & $0.5685(2)$ & $0.2032(2)$ & $0.13447(16)$ & $0.0328(3)$ \\
\hline $\mathrm{H} 2 \mathrm{~N}$ & $0.522(3)$ & $0.167(3)$ & $0.1913(19)$ & $0.045(7)^{*}$ \\
\hline $\mathrm{C} 1$ & $1.1930(3)$ & $0.6341(3)$ & $0.22886(19)$ & $0.0388(4)$ \\
\hline H1 & 1.278903 & 0.712666 & 0.201889 & $0.047^{*}$ \\
\hline $\mathrm{C} 2$ & $1.0017(3)$ & $0.5676(2)$ & 0.17938 (19) & $0.0365(4)$ \\
\hline $\mathrm{H} 2$ & 0.958087 & 0.600506 & 0.119978 & $0.044 *$ \\
\hline $\mathrm{C} 3$ & $0.8745(3)$ & $0.4522(2)$ & $0.21761(18)$ & $0.0339(4)$ \\
\hline $\mathrm{C} 4$ & $0.9465(3)$ & $0.4093(3)$ & $0.3046(2)$ & $0.0444(5)$ \\
\hline $\mathrm{H} 4$ & 0.863962 & 0.330319 & 0.332615 & $0.053 *$ \\
\hline $\mathrm{C} 5$ & $1.1384(3)$ & $0.4818(3)$ & $0.3502(2)$ & $0.0459(5)$ \\
\hline H5 & 1.185252 & 0.452059 & 0.410711 & $0.055^{*}$ \\
\hline C6 & $0.6630(3)$ & $0.3820(2)$ & $0.1718(2)$ & $0.0381(4)$ \\
\hline H6A & 0.608278 & 0.441956 & 0.244426 & $0.046^{*}$ \\
\hline H6B & 0.639555 & 0.402602 & 0.094503 & $0.046^{*}$ \\
\hline C7 & $0.5558(2)$ & 0.0917 (2) & 0.01203 (17) & $0.0291(4)$ \\
\hline
\end{tabular}


Atomic displacement parameters $\left(\AA^{2}\right)$

\begin{tabular}{lllllll}
\hline & $U^{11}$ & $U^{22}$ & $U^{33}$ & $U^{12}$ & $U^{13}$ & $U^{23}$ \\
\hline C11 & $0.0348(3)$ & $0.0602(3)$ & $0.0397(3)$ & $0.0143(2)$ & $-0.0083(2)$ & $0.0140(2)$ \\
O2 & $0.0246(6)$ & $0.0723(10)$ & $0.0315(7)$ & $0.0152(6)$ & $0.0036(5)$ & $0.0177(7)$ \\
O3 & $0.0292(7)$ & $0.0445(8)$ & $0.0298(7)$ & $0.0093(6)$ & $0.0013(5)$ & $0.0124(6)$ \\
C8 & $0.0287(9)$ & $0.0384(9)$ & $0.0297(9)$ & $0.0112(7)$ & $0.0039(7)$ & $0.0173(8)$ \\
C9 & $0.0262(8)$ & $0.0363(9)$ & $0.0333(9)$ & $0.0109(7)$ & $0.0041(7)$ & $0.0187(8)$ \\
C10 & $0.0323(9)$ & $0.0355(9)$ & $0.0369(10)$ & $0.0145(7)$ & $0.0081(8)$ & $0.0189(8)$ \\
C11 & $0.0286(9)$ & $0.0456(11)$ & $0.0496(12)$ & $0.0176(8)$ & $0.0127(8)$ & $0.0269(10)$ \\
C12 & $0.0241(8)$ & $0.0452(10)$ & $0.0515(12)$ & $0.0113(7)$ & $0.0023(8)$ & $0.0289(10)$ \\
C13 & $0.0286(9)$ & $0.0414(10)$ & $0.0371(10)$ & $0.0114(7)$ & $-0.0005(7)$ & $0.0199(8)$ \\
C14 & $0.0259(8)$ & $0.0426(10)$ & $0.0354(10)$ & $0.0132(7)$ & $0.0043(7)$ & $0.0194(8)$ \\
O1 & $0.0242(6)$ & $0.0417(7)$ & $0.0306(7)$ & $0.0080(5)$ & $0.0035(5)$ & $0.0186(6)$ \\
N1 & $0.0319(8)$ & $0.0360(8)$ & $0.0355(9)$ & $0.0028(6)$ & $-0.0022(6)$ & $0.0155(7)$ \\
N2 & $0.0246(7)$ & $0.0362(8)$ & $0.0278(8)$ & $0.0053(6)$ & $0.0000(6)$ & $0.0117(6)$ \\
C1 & $0.0372(10)$ & $0.0420(10)$ & $0.0309(9)$ & $0.0058(8)$ & $0.0040(8)$ & $0.0199(8)$ \\
C2 & $0.0387(10)$ & $0.0393(10)$ & $0.0290(9)$ & $0.0107(8)$ & $0.0017(7)$ & $0.0177(8)$ \\
C3 & $0.0320(9)$ & $0.0301(9)$ & $0.0284(9)$ & $0.0057(7)$ & $-0.0022(7)$ & $0.0091(7)$ \\
C4 & $0.0342(10)$ & $0.0393(10)$ & $0.0503(12)$ & $-0.0023(8)$ & $-0.0080(9)$ & $0.0273(10)$ \\
C5 & $0.0380(11)$ & $0.0423(11)$ & $0.0511(13)$ & $0.0019(8)$ & $-0.0099(9)$ & $0.0284(10)$ \\
C6 & $0.0318(9)$ & $0.0365(10)$ & $0.0366(10)$ & $0.0095(8)$ & $-0.0019(8)$ & $0.0117(8)$ \\
C7 & $0.0169(7)$ & $0.0381(9)$ & $0.0279(8)$ & $0.0069(7)$ & $-0.0012(6)$ & $0.0146(7)$ \\
& & & & & &
\end{tabular}

Geometric parameters $\left(A,{ }^{\circ}\right)$

\begin{tabular}{llll}
\hline $\mathrm{C} 11-\mathrm{C} 13$ & $1.746(2)$ & $\mathrm{N} 1-\mathrm{C} 5$ & $1.340(3)$ \\
$\mathrm{O} 2-\mathrm{C} 8$ & $1.225(2)$ & $\mathrm{N} 2-\mathrm{H} 2 \mathrm{~N}$ & $0.857(10)$ \\
$\mathrm{O} 3-\mathrm{H} 3 \mathrm{O}$ & $0.846(10)$ & $\mathrm{N} 2-\mathrm{C} 6$ & $1.453(2)$ \\
$\mathrm{O} 3-\mathrm{C} 8$ & $1.308(2)$ & $\mathrm{N} 2-\mathrm{C} 7$ & $1.326(2)$ \\
$\mathrm{C} 8-\mathrm{C} 9$ & $1.499(2)$ & $\mathrm{C} 1-\mathrm{H} 1$ & 0.9500 \\
$\mathrm{C} 9-\mathrm{C} 10$ & $1.395(3)$ & $\mathrm{C} 1-\mathrm{C} 2$ & $1.385(3)$ \\
$\mathrm{C} 9-\mathrm{C} 14$ & $1.391(3)$ & $\mathrm{C} 2-\mathrm{H} 2$ & 0.9500 \\
$\mathrm{C} 10-\mathrm{H} 10$ & 0.9500 & $\mathrm{C} 2-\mathrm{C} 3$ & $1.389(3)$ \\
$\mathrm{C} 10-\mathrm{C} 11$ & $1.386(3)$ & $\mathrm{C} 3-\mathrm{C} 4$ & $1.385(3)$ \\
$\mathrm{C} 11-\mathrm{H} 11$ & $\mathrm{C} 3-\mathrm{C} 6$ & $1.517(3)$ \\
$\mathrm{C} 11-\mathrm{C} 12$ & $1.382(3)$ & $\mathrm{C} 4-\mathrm{H} 4$ & 0.9500 \\
$\mathrm{C} 12-\mathrm{H} 12$ & 0.9500 & $\mathrm{C} 4-\mathrm{C} 5$ & $1.376(3)$ \\
$\mathrm{C} 12-\mathrm{C} 13$ & $1.386(3)$ & $\mathrm{C} 5-\mathrm{H} 5$ & 0.9500 \\
$\mathrm{C} 13-\mathrm{C} 14$ & $1.386(3)$ & $\mathrm{C} 6-\mathrm{H} 6 \mathrm{~A}$ & 0.9900 \\
$\mathrm{C} 14-\mathrm{H} 14$ & 0.9500 & $\mathrm{C} 6-\mathrm{H} 6 \mathrm{~B}$ & 0.9900 \\
$\mathrm{O} 1-\mathrm{C} 7$ & $\mathrm{C} 7-\mathrm{C} 7 \mathrm{i}$ & $1.539(3)$ \\
$\mathrm{N} 1-\mathrm{C} 1$ & $1.228(2)$ & & $120.72(16)$ \\
& $1.340(3)$ & $\mathrm{C} 7-\mathrm{N} 2-\mathrm{C} 6$ & 118.6 \\
$\mathrm{C} 8-\mathrm{O} 3-\mathrm{H} 3 \mathrm{O}$ & & $\mathrm{N} 1-\mathrm{C} 1-\mathrm{H} 1$ & $122.84(17)$ \\
$\mathrm{O} 2-\mathrm{C} 8-\mathrm{O} 3$ & $110(2)$ & $\mathrm{N} 1-\mathrm{C} 1-\mathrm{C} 2$ & 118.6 \\
$\mathrm{O} 2-\mathrm{C} 8-\mathrm{C} 9$ & $123.38(17)$ & $\mathrm{C} 2-\mathrm{C} 1-\mathrm{H} 1$ & \\
$\mathrm{O} 3-\mathrm{C} 8-\mathrm{C} 9$ & $122.38(17)$ & &
\end{tabular}




\begin{tabular}{|c|c|c|c|}
\hline $\mathrm{C} 10-\mathrm{C} 9-\mathrm{C} 8$ & $120.62(17)$ & $\mathrm{C} 1-\mathrm{C} 2-\mathrm{H} 2$ & 120.4 \\
\hline $\mathrm{C} 14-\mathrm{C} 9-\mathrm{C} 8$ & $119.03(16)$ & $\mathrm{C} 1-\mathrm{C} 2-\mathrm{C} 3$ & $119.22(18)$ \\
\hline $\mathrm{C} 14-\mathrm{C} 9-\mathrm{C} 10$ & $120.35(17)$ & $\mathrm{C} 3-\mathrm{C} 2-\mathrm{H} 2$ & 120.4 \\
\hline $\mathrm{C} 9-\mathrm{C} 10-\mathrm{H} 10$ & 120.3 & $\mathrm{C} 2-\mathrm{C} 3-\mathrm{C} 6$ & $121.38(18)$ \\
\hline $\mathrm{C} 11-\mathrm{C} 10-\mathrm{C} 9$ & $119.44(19)$ & $\mathrm{C} 4-\mathrm{C} 3-\mathrm{C} 2$ & $117.76(17)$ \\
\hline $\mathrm{C} 11-\mathrm{C} 10-\mathrm{H} 10$ & 120.3 & $\mathrm{C} 4-\mathrm{C} 3-\mathrm{C} 6$ & $120.78(17)$ \\
\hline $\mathrm{C} 10-\mathrm{C} 11-\mathrm{H} 11$ & 119.5 & $\mathrm{C} 3-\mathrm{C} 4-\mathrm{H} 4$ & 120.2 \\
\hline $\mathrm{C} 12-\mathrm{C} 11-\mathrm{C} 10$ & $121.04(18)$ & $\mathrm{C} 5-\mathrm{C} 4-\mathrm{C} 3$ & $119.60(18)$ \\
\hline $\mathrm{C} 12-\mathrm{C} 11-\mathrm{H} 11$ & 119.5 & $\mathrm{C} 5-\mathrm{C} 4-\mathrm{H} 4$ & 120.2 \\
\hline $\mathrm{C} 11-\mathrm{C} 12-\mathrm{H} 12$ & 120.7 & $\mathrm{~N} 1-\mathrm{C} 5-\mathrm{C} 4$ & $122.98(19)$ \\
\hline $\mathrm{C} 11-\mathrm{C} 12-\mathrm{C} 13$ & $118.63(17)$ & $\mathrm{N} 1-\mathrm{C} 5-\mathrm{H} 5$ & 118.5 \\
\hline $\mathrm{C} 13-\mathrm{C} 12-\mathrm{H} 12$ & 120.7 & $\mathrm{C} 4-\mathrm{C} 5-\mathrm{H} 5$ & 118.5 \\
\hline $\mathrm{C} 12-\mathrm{C} 13-\mathrm{Cl1}$ & $119.31(15)$ & $\mathrm{N} 2-\mathrm{C} 6-\mathrm{C} 3$ & $112.60(16)$ \\
\hline $\mathrm{C} 14-\mathrm{C} 13-\mathrm{C} 11$ & $118.88(15)$ & $\mathrm{N} 2-\mathrm{C} 6-\mathrm{H} 6 \mathrm{~A}$ & 109.1 \\
\hline $\mathrm{C} 14-\mathrm{C} 13-\mathrm{C} 12$ & $121.81(19)$ & $\mathrm{N} 2-\mathrm{C} 6-\mathrm{H} 6 \mathrm{~B}$ & 109.1 \\
\hline C9-C14-H14 & 120.6 & $\mathrm{C} 3-\mathrm{C} 6-\mathrm{H} 6 \mathrm{~A}$ & 109.1 \\
\hline $\mathrm{C} 13-\mathrm{C} 14-\mathrm{C} 9$ & $118.72(18)$ & $\mathrm{C} 3-\mathrm{C} 6-\mathrm{H} 6 \mathrm{~B}$ & 109.1 \\
\hline $\mathrm{C} 13-\mathrm{C} 14-\mathrm{H} 14$ & 120.6 & $\mathrm{H} 6 \mathrm{~A}-\mathrm{C} 6-\mathrm{H} 6 \mathrm{~B}$ & 107.8 \\
\hline $\mathrm{C} 5-\mathrm{N} 1-\mathrm{C} 1$ & $117.60(17)$ & $\mathrm{O} 1-\mathrm{C} 7-\mathrm{N} 2$ & $124.94(17)$ \\
\hline $\mathrm{C} 6-\mathrm{N} 2-\mathrm{H} 2 \mathrm{~N}$ & $120.9(16)$ & $\mathrm{O} 1-\mathrm{C} 7-\mathrm{C}^{\mathrm{i}}$ & $121.2(2)$ \\
\hline $\mathrm{C} 7-\mathrm{N} 2-\mathrm{H} 2 \mathrm{~N}$ & $118.3(16)$ & $\mathrm{N} 2-\mathrm{C} 7-\mathrm{C}^{\mathrm{i}}$ & $113.87(19)$ \\
\hline $\mathrm{C} 11-\mathrm{C} 13-\mathrm{C} 14-\mathrm{C} 9$ & $179.18(14)$ & $\mathrm{N} 1-\mathrm{C} 1-\mathrm{C} 2-\mathrm{C} 3$ & $-0.2(3)$ \\
\hline $\mathrm{O} 2-\mathrm{C} 8-\mathrm{C} 9-\mathrm{C} 10$ & $171.79(19)$ & $\mathrm{C} 1-\mathrm{N} 1-\mathrm{C} 5-\mathrm{C} 4$ & $0.7(3)$ \\
\hline $\mathrm{O} 2-\mathrm{C} 8-\mathrm{C} 9-\mathrm{C} 14$ & $-8.8(3)$ & $\mathrm{C} 1-\mathrm{C} 2-\mathrm{C} 3-\mathrm{C} 4$ & $0.1(3)$ \\
\hline $\mathrm{O} 3-\mathrm{C} 8-\mathrm{C} 9-\mathrm{C} 10$ & $-8.1(2)$ & $\mathrm{C} 1-\mathrm{C} 2-\mathrm{C} 3-\mathrm{C} 6$ & $176.96(19)$ \\
\hline $\mathrm{O} 3-\mathrm{C} 8-\mathrm{C} 9-\mathrm{C} 14$ & $171.32(17)$ & $\mathrm{C} 2-\mathrm{C} 3-\mathrm{C} 4-\mathrm{C} 5$ & $0.4(3)$ \\
\hline $\mathrm{C} 8-\mathrm{C} 9-\mathrm{C} 10-\mathrm{C} 11$ & $-179.40(17)$ & $\mathrm{C} 2-\mathrm{C} 3-\mathrm{C} 6-\mathrm{N} 2$ & $138.48(19)$ \\
\hline $\mathrm{C} 8-\mathrm{C} 9-\mathrm{C} 14-\mathrm{C} 13$ & $-179.43(17)$ & $\mathrm{C} 3-\mathrm{C} 4-\mathrm{C} 5-\mathrm{N} 1$ & $-0.8(4)$ \\
\hline $\mathrm{C} 9-\mathrm{C} 10-\mathrm{C} 11-\mathrm{C} 12$ & $-1.3(3)$ & $\mathrm{C} 4-\mathrm{C} 3-\mathrm{C} 6-\mathrm{N} 2$ & $-44.8(3)$ \\
\hline $\mathrm{C} 10-\mathrm{C} 9-\mathrm{C} 14-\mathrm{C} 13$ & $0.0(3)$ & $\mathrm{C} 5-\mathrm{N} 1-\mathrm{C} 1-\mathrm{C} 2$ & $-0.2(3)$ \\
\hline $\mathrm{C} 10-\mathrm{C} 11-\mathrm{C} 12-\mathrm{C} 13$ & $0.3(3)$ & $\mathrm{C} 6-\mathrm{N} 2-\mathrm{C} 7-\mathrm{O} 1$ & $1.8(3)$ \\
\hline $\mathrm{C} 11-\mathrm{C} 12-\mathrm{C} 13-\mathrm{C} 11$ & $-179.29(15)$ & $\mathrm{C} 6-\mathrm{N} 2-\mathrm{C} 7-\mathrm{C}^{\mathrm{i}}$ & $-177.61(17)$ \\
\hline $\mathrm{C} 11-\mathrm{C} 12-\mathrm{C} 13-\mathrm{C} 14$ & $1.0(3)$ & $\mathrm{C} 6-\mathrm{C} 3-\mathrm{C} 4-\mathrm{C} 5$ & $-176.5(2)$ \\
\hline $\mathrm{C} 12-\mathrm{C} 13-\mathrm{C} 14-\mathrm{C} 9$ & $-1.1(3)$ & $\mathrm{C} 7-\mathrm{N} 2-\mathrm{C} 6-\mathrm{C} 3$ & $-86.3(2)$ \\
\hline $\mathrm{C} 14-\mathrm{C} 9-\mathrm{C} 10-\mathrm{C} 11$ & $1.2(3)$ & & \\
\hline
\end{tabular}

Symmetry code: (i) $-x+1,-y,-z$.

Hydrogen-bond geometry $\left(A,{ }^{\circ}\right)$

$\mathrm{Cg} 1$ is the centroid of the (N1,C1-C5) ring.

\begin{tabular}{lllll}
\hline$D-\mathrm{H} \cdots A$ & $D-\mathrm{H}$ & $\mathrm{H} \cdots A$ & $D \cdots A$ & $D-\mathrm{H} \cdots A$ \\
\hline $\mathrm{N} 2-\mathrm{H} 2 N \cdots \mathrm{O} 1^{\mathrm{i}}$ & $0.86(2)$ & $2.34(3)$ & $2.717(2)$ & $107(2)$ \\
$\mathrm{N} 2-\mathrm{H} 2 N \cdots \mathrm{O} 2^{\mathrm{ii}}$ & $0.86(2)$ & $2.08(2)$ & $2.863(2)$ & $151(2)$ \\
$\mathrm{O} 3-\mathrm{H} 3 O \cdots \mathrm{N} 1^{\mathrm{iii}}$ & $0.84(2)$ & $1.74(2)$ & $2.581(2)$ & $174(4)$ \\
$\mathrm{C} 14-\mathrm{H} 14 \cdots \mathrm{O} 1^{\text {iv }}$ & 0.95 & 2.37 & $3.286(2)$ & 161 \\
$\mathrm{C} 1-\mathrm{H} 1 \cdots{ }^{\mathrm{i}} 1^{\mathrm{v}}$ & 0.95 & 2.39 & $3.286(3)$ & 157
\end{tabular}


supporting information

$\begin{array}{lllll}\mathrm{C} 12-\mathrm{H} 12 \cdots \mathrm{O} 1^{\mathrm{vi}} & 0.95 & 2.46 & 3.328(3) & 152 \\ \mathrm{C} 6-\mathrm{H} 6 A \cdots \mathrm{O} 3 & 0.99 & 2.50 & 3.400(3) & 151 \\ \mathrm{C} 13-\mathrm{C} 11 \cdots \mathrm{Cg} 1 & 1.75(1) & 3.83(1) & 5.358(2) & 145(1)\end{array}$

Symmetry codes: (i) $-x+1,-y,-z$; (ii) $-x+1,-y+1,-z+1$; (iii) $x-1, y, z$; (iv) $x, y+1, z+1$; (v) $-x+2,-y+1,-z$; (vi) $x+1, y+1, z+1$. 